\title{
Implementation of Green Tax in Malaysia: An Exploratory Study
}

\author{
Natrah Saad ${ }^{1}$ \\ Zaimah Zainol Ariffin ${ }^{2}$
}

Tunku Puteri Intan Safinaz School of Accountancy, Universiti Utara Malaysia, Malaysia.

Email:natrah@uum.edu.my Tel: +6049287285

EEmail:zaimah@uum.edu.my.Tel:+6049287339

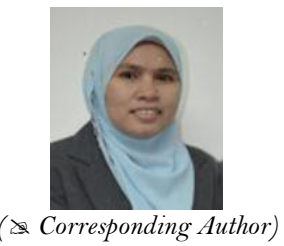

\section{Abstract}

This study provides empirical evidence on the perception of green tax mechanisms that are currently implemented in Malaysia. This study is undertaken in response to increasing incidents of environmental degradation taking place in our country as a result of business activities. In particular, this study sets to explore the current practice of green tax in Malaysia and its effectiveness in achieving the intended goal of green environment. For that purpose, a qualitative approach of data collection was conducted, mainly through interviews and document review. Hence, 11 participants representing government agencies and industries were interviewed and data gathered were transcribed and analysed accordingly using thematic analysis. Annual reports and performance reports were also reviewed to complement the findings. Among others, the findings indicate that green tax practice in Malaysia is merely focused on incentive-based which are under jurisdiction of Malaysian Investment Development Authority and the Inland Revenue Board Malaysia (IRBM). The authority to impose penalties (which are not related to tax) rests with the Department of Environment. The practice is slightly different from the developed country which blends both incentive-based and penalty-based under jurisdiction of the tax authority. It is hoped that these findings would assist the relevant agencies to formulate the strategies in their effort to preserve our natural heritage.

Keywords: Green tax, Penalty-based, Incentive-based, Framework, Environment, Malaysia.

Citation I Natrah Saad; Zaimah Zainol Ariffin (2019). Implementation of Green Tax in Malaysia: An Exploratory Study Growth, 6(1): 12-19.

History:

Received: 7 June 2019

Received: 7 June 2019

Accepted: 13 August 2019

Published: 24 September 2019

Licensed: This work is licensed under a Creative Commons Attribution 3.0 License $(\mathrm{coc})$

Publisher: Asian Online Journal Publishing Group
Acknowledgement: Both authors contributed to the conception and design of the study.

Funding: Authors would like to thank Universiti Utara Malaysia (UUM), Research and Innovation Management Centre of UUM, and Tunku Puteri Intan Safinaz School of Accountancy, UUM (TISSA-UUM) for awarding the grant and the support to make this research feasible.

Competing Interests: The authors declare that they have no conflict of Competing
interests.

Transparency: The authors confirm that the manuscript is an honest, accurate, and transparent account of the study was reported; that no vital features of the study have been omitted; and that any discrepancies from the study as planned have been explained.

Ethical: This study follows all ethical practices during writing.

\section{Contents}

1. Introduction

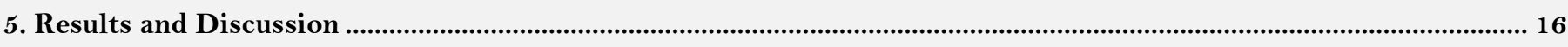



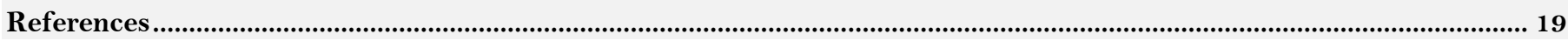




\section{Contribution of this paper to the literature}

This study contributes to the literature by examining the green tax practices in Malaysian environment from the perspectives of policy makers and industry players.

\section{Introduction}

Globally, the concern with the environment and energy usage is increasingly becoming the focus of attention. Countries like Denmark, Sweden, Germany, the United Kingdom (UK) and the United States (US), are proactively involved in protecting the environment and promoting a sustainable future by enacting various laws (Fullerton et al., 2008). To be at par with this global movement, Malaysia launched a National Green Technology Policy in July 2009 as part of its national policy. The policy which is based on four pillars, namely energy, environment, economy and social perspectives is set to harmonise economic development goals with environmental imperatives (Hong, 2010).

The commitment to a sustainable Malaysia by reducing carbon emission by up to $40 \%$ was affirmed by the Prime Minister's declaration at the United Nations Climate Change Conference in Copenhagen, Denmark in December 2009 ( $\mathrm{PwC}$, 2010). Consistent with this agenda, Malaysia has been strengthening the enforcement of the Acts relating to environmental protection, revising companies' financial reporting requirements and improving the current tax legislations, the third measure being the focus of this research.

The use of tax legislations to encourage sustainability is not an uncommon exercise worldwide (such as in Europe and the US) (Bluffstone, 2003). It can actually be implemented in two ways: (i) by providing incentives (for non-polluters) or imposing penalties (for polluters); or (ii) both. While the use of the second carrot and stick approach has been claimed to be the more meaningful and fair approach to industry players and society at large, Malaysia has to date, adopted only the incentives approach (as highlighted in the budget of the past few years) in its effort to encourage a green environment. However, evidences of the positive impacts of this kind of approach are not discernible, considering the alarming level of environmental abuse reported in the media nowadays.

Thus, the researchers believe that it is timely to examine the current practice of green (environmental) taxation in Malaysia; and how effective it has been in attaining a green environment in Malaysia. This study is significant in a number of ways. First, the study provides insight to policy makers on the perception of the current practice of green tax in Malaysia and its effectiveness. It highlights the relevance and the scope for improvement in relation to green tax. Second, the study recommends other plausible approach of green tax to be implemented in Malaysia based on the practices around the globe.

The remainder of this paper is organised as follows: In Section 2, the literature review on the background and issues related to green tax within and outside Malaysia are discussed. Next, the research methodology is outlined in Section 3. The findings and discussions are reported in Section 4, followed by conclusions and recommendations for future research in Section 5.

\section{Major Agencies Engaged in Green Tax in Malaysia}

Generally there are two major agencies which are directly involved in the implementation of green tax in Malaysia. The agencies are Malaysian Investment Development Authority (MIDA) and the Inland Revenue Board Malaysia (IRBM). Their roles are discussed in the following sub-sections.

\subsection{Malaysian Investment Development Authority}

MIDA, which was incorporated under the Malaysian Industrial Development Authority Act 1967, is a governmental agency for the promotion of the manufacturing and services sectors in Malaysia. MIDA assists companies which intend to invest in the manufacturing and services sectors, and facilitates the implementation of their projects. The wide range of services provided by MIDA includes information on the opportunities for investments and facilitating companies which are looking for joint venture partners. One of MIDA's roles is the one-stop processing centre for the application of tax incentives. Malaysia offers a wide range of tax incentives for manufacturing projects under the Promotion of Investments Act 1986 and the Income Tax Act 1967. The main incentives are Pioneer Status, Investment Tax Allowance (ITA), Reinvestment Allowance, Incentives for High Technology Industries, Incentives for Strategic Projects and Incentives for the Setting-up of International/Regional Service-based Operations. In spite of the various incentives available, this study focuses mainly on tax incentives for green technology.

Green technology is defined as the development and application of products, equipment and systems used to conserve the natural environment and resources, which can minimise and reduce the negative impact of human activities. Green technology is one of the drivers of the economy that can contribute to overall green growth and sustainable development. In line with Malaysia's aim to become an inclusive and sustainably advanced nation by 2020, under the National Green Technology Policy, the cross-sectoral green technology focuses on four sectors, that is efficient utilization of energy, greening the building sector, recycle waste management and greening the transport sector. Under Budget 2014, the Green Investment Tax Allowance (GITA) for the purchase of green technology assets and Green Income Tax Exemption (GITE) on the use of green technology services and system, were introduced to further strengthen the development of green technology. Projects which qualify for this incentive are renewable energy, energy efficiency, integrated waste management and green building or green data centre projects. In addition, eligible services activities include system integration of renewable energy, energy services, services related to green building or green data centre, green certification of products, equipment \& building and Green Township.

Tax incentives for green industries comprise: (i) incentives for qualifying activities; and (ii) incentives for establishment of Waste Eco Parks (WEPs). The aim of green technology incentives for qualifying activities is to strengthen the development of green technology. Green technology incentives for qualifying activities are divided into three, i.e., tax incentive for green technology projects, services and assets. 
The tax incentive for green technology services offers ITE of $100 \%$ of statutory income from the year of assessment 2013 until the year of assessment 2020. Green technology services related to renewable energy (RE), energy efficiency $(\mathrm{EE})$, electric vehicle $(\mathrm{EV})$, green building, green data centre, green certification and verification and green township, can qualify for this tax incentive.

The tax incentive for purchase of green technology assets involves ITA of $100 \%$ of qualifying capital expenditure incurred on green technology assets from the year of assessment 2013 until the year of assessment 2020. The allowance can be offset against $70 \%$ of statutory income in the year of assessment. Unutilised allowances can be carried forward until they are fully absorbed. Green technology assets are listed in MyHijau Directory (www.greendirectory.my), and are certified by the Malaysia Green Technology Corporation (MGTC) and approved by the Ministry of Finance (MOF).

The other tax incentives available are the incentives for establishment of WEPs. WEPs aim to promote waste recycling, recovery and treatment activities by the industries and provide a sustainable solution to the waste management problem. This will encourage investments in facilities and infrastructure towards holistic waste management activities. In order to promote the activities, there are incentives available for: (i) WEP Developers; (ii) WEP Managers; and (iii) WEP Operators (companies operating in the WEP).

Tax incentive for WEP developers (companies) is income tax exemption of $70 \%$ on statutory business income derived from rental of building, fees received from the usage of waste collection and separation facility and fees received from waste water treatment facility located in the WEP. Tax incentive for WEP managers (companies) is income tax exemption of $70 \%$ on statutory business income derived from service activities relating to management, maintenance, supervision and marketing of the WEP. Tax incentive for WEP operators (companies) is income tax exemption of $100 \%$ on statutory business income for a period of five years, derived from the qualifying activities, i.e., waste treatment, waste recovery and waste recycling, undertaken in the WEP. The ITA of 100\% qualifying capital expenditure incurred (within five years) can be offset against $70 \%$ of statutory business income.

\subsection{Inland Revenue Board Malaysia}

Malaysia, through the IRBM offers a wide range of tax incentives, ranging from tax exemptions and allowances based on capital expenditure to enhance tax deductions. For incentives by way of allowances, any unutilised allowances can generally be carried forward until fully utilised. These tax incentives are generally available for tax resident companies. In relation to tax incentives for green environment, Malaysia focuses on three green areas, i.e.: (i) renewable energy and fuels; (ii) material resources and waste; and (iii) pollution and ecosystems.

\section{i. Renewable Energy and Fuels}

In calendar years 2013 to 2020, companies which purchased/will be purchasing and used/will be using green technology assets qualify for ITA of $100 \%$ of qualifying capital expenditure. The allowance can be offset against $70 \%$ of statutory income. Green technology assets are defined as green technology products, equipment or systems used to conserve the natural environment and resources that minimise and reduce the negative impact of human activities. Furthermore, companies undertaking generation of energy from renewable resources are eligible for pioneer status incentives, which provide income tax exemption of $100 \%$ of statutory income for 10 years. Other than that, certain locally and non-locally produced machinery and equipment purchased for the generation of energy using biomass are exempt from import duty and sales tax.

\section{ii. Material Resources and Waste}

Companies providing energy conservation services are eligible for various incentives, including pioneer status and ITA. ITE orders on WEP incentives were issued on 15 August 2017. Income Tax (Exemption) (No 4) Order 2017 is for ITA for WEP operators; Income Tax (Exemption) (No 5) Order 2017 is for ITE for WEP operators; Income Tax (Exemption) (No 6) Order 2017 is for ITE for WEP managers; and Income Tax (Exemption) (No 7) Order 2017 is for ITE for WEP developers.

\section{iii. Pollution and Ecosystems}

Companies that undertake forest plantation projects are eligible for pioneer status and ITA incentives under the Promotion of Investment Acts 1986. Also, companies that undertake forest plantation projects can apply for incentives, such as tax deduction.

\section{Green Tax Adopted in Selected Countries}

In Japan, the government introduced a new tax to curb carbon emissions in 2012. The Chinese government also has resource taxes on six minerals, including iron and tin ore. The objective of China's policy is to conserve domestic mineral resources and the environment. Colombia, in 2015, established an action plan with strategies, including incentives, to achieve reduced environmental impacts, improved quality of life and access to clean and renewable energy sources. Chile established a carbon tax in 2014, as part of its government's tax reform initiative. In addition, in 2016, Chile implemented a green tax on all new vehicles sold. Mexico, which in 2013 had little focus on environmental protection, has recently addressed the issue. In 2016, Mexico passed the General Law for Environmental Protection, which imposes penalties on entities that create environmental damage. Also, in 2016, Argentina, focused on the development of clean energy, in particular, solar and wind power, as well as longstanding tax policies, to ensure the success of renewables. The plan allows tax incentives for businesses that develop clean energy projects.

The KPMG Green Tax Index (2013) has created the Green Tax Index to increase awareness of the green tax landscape worldwide and encourage companies to explore the opportunities for green tax incentives and reduce their exposure to green tax penalties. The index as set out in Table 1 offers an overview of the green tax landscape around the world, particularly to 21 major (economies) countries. The principles used to create this index, include the ease or complexity of the incentive claim process, long or short-term duration, availability of incentives and flexibility to transfer or carry forward tax benefits. It has been identified that 200 individual tax incentives and 
penalties are related to corporate sustainability. At least 30 of these individual tax incentives and penalties have been introduced since January 2011. In addition, the index provides the ranking of green tax policy across countries. The first column shows the overall country rankings based on the set index; while, the next two columns show the country ranking based on tax incentives and tax penalties index, respectively. This may be useful to governments, particularly those in the early stages of formulating a green tax policy.

Table-1. Green tax index in major countries.

\begin{tabular}{|c|c|c|c|c|}
\hline No. & Major countries & Overall ranking & Tax incentives ranking & Tax penalties ranking \\
\hline 1 & $\overline{\mathrm{US}}$ & 1 & 1 & 14 \\
\hline 2 & Japan & 2 & 8 & 2 \\
\hline 3 & UK & 3 & 5 & 3 \\
\hline 4 & France & 4 & 16 & 1 \\
\hline 5 & South Korea & 5 & 2 & 9 \\
\hline 6 & China & 6 & 3 & 5 \\
\hline 7 & Ireland & 7 & 9 & 6 \\
\hline 8 & Netherlands & 8 & 6 & 9 \\
\hline 9 & Belgium & 9 & 10 & 9 \\
\hline 10 & India & 10 & 4 & 17 \\
\hline 11 & Spain & \multirow{2}{*}{11} & 15 & 6 \\
\hline 12 & Canada & & 6 & 16 \\
\hline 13 & South Africa & 13 & 12 & 9 \\
\hline 14 & Singapore & 14 & 11 & 15 \\
\hline 15 & Finland & \multirow{2}{*}{15} & 21 & 4 \\
\hline 16 & Germany & & 17 & 9 \\
\hline 17 & Australia & 17 & 19 & 6 \\
\hline 18 & Brazil & 18 & 12 & 19 \\
\hline 19 & Argentina & 19 & 14 & 19 \\
\hline 20 & Mexico & 20 & 18 & 19 \\
\hline 21 & Russia & 21 & 20 & 17 \\
\hline
\end{tabular}

The US tops the overall ranking primarily due to its extensive programme of federal tax incentives for EE, RE and green buildings. Even though the US tops the ranking of tax incentives for green tax, it is ranked $14^{\text {th }}$ for tax penalties, indicating that its green tax policy is weighted heavily in favour of incentives. The US uses green tax penalties less than other western developed nations, apart from Canada. The countries which impose fewer green tax penalties are mostly emerging economies, such as Mexico, Brazil, Argentina and India. For overall ranking, Japan is ranked second after the US, but scores higher on green tax penalties than it does on green incentives.

In 2017, KPMG member firms analysed the green tax policy for major economies based on five green areas, i.e., carbon and climate change, renewable energy and fuels, material resources and waste, pollution and ecosystems and innovation. Table 2 shows the analysis of the report presented in TKPMGGTI (2017). The analysis is organised by countries which provide carbon taxes, tax incentives and penalties based on the five green areas. The countries, including Chile, India, Spain, Sweden, Taiwan and the UK, established carbon tax and pollution tax in 2014, as part of the 2014 tax reform legislation. In contrast, the United Arab Emirates (UAE) does not use taxes as a tool to regulate environmental issues in the country. However, in 2016, the UAE launched a nationwide campaign on eco-programmes for 12 months, encompassing an awareness campaign, community engagement and green initiatives. Other than that, in order to lower the emission level of vehicles, the UAE recently raised awareness and educated the target audience through campaigns to encourage the citizens to use more sustainable transportation.

Singapore ratified the Paris Agreement 2016, to reduce greenhouse gas emission by 2020. In relation to this, Singapore announced the implementation of carbon tax starting from year 2019. Singapore also provides tax incentives for RE companies, accelerated capital allowance for approved efficient pollution control equipment or devices and tax deduction on innovative-related activities.

\section{Research Method}

This study adopted a qualitative approach with a semi-structured interview to answer the objectives of the study. This approach is considered appropriate as the researchers are interested to have an in-depth understanding of the issue. Semi-structured, face-to-face interviews were conducted with an officer each from IRBM and MIDA, representing the policymakers. In addition, interviews were conducted with one practitioner from an oil and gas company and eight personnel from the hotel industry. Their views were obtained to represent the respective industry. The interview sessions were recorded and transcribed accordingly. The transcripts were then analysed using thematic analysis, following Braun and Clarke (2006). In addition, relevant documents were reviewed to substantiate the findings. 
Table-2. Carbon taxes, tax incentives and penalties across countries.

\begin{tabular}{|c|c|c|c|c|c|c|}
\hline No. & Country & $\begin{array}{l}\text { Carbon and } \\
\text { climate } \\
\text { change }\end{array}$ & $\begin{array}{l}\text { Renewable } \\
\text { energy and } \\
\text { fuels }\end{array}$ & $\begin{array}{c}\text { Material } \\
\text { resources and } \\
\text { waste }\end{array}$ & $\begin{array}{c}\text { Pollution } \\
\text { and } \\
\text { ecosystems }\end{array}$ & Innovation \\
\hline 1 & Argentina & & $\sqrt{ }$ & $\sqrt{ }$ & & \\
\hline 2 & Australia & & $\sqrt{ }$ & $\sqrt{ }$ & $\sqrt{ }$ & $\sqrt{ }$ \\
\hline 3 & Brazil & & $\sqrt{ }$ & $\sqrt{ }$ & $\sqrt{ }$ & $\sqrt{ }$ \\
\hline 4 & Canada & $\sqrt{ }$ & $\sqrt{ }$ & & & $\sqrt{ }$ \\
\hline 5 & Chile & $\sqrt{ }$ & $\sqrt{ }$ & $\sqrt{ }$ & $\sqrt{ }$ & $\sqrt{ }$ \\
\hline 6 & Columbia & & $\sqrt{ }$ & $\sqrt{ }$ & $\sqrt{ }$ & $\sqrt{ }$ \\
\hline 7 & Czech Republic & & $\sqrt{ }$ & $\sqrt{ }$ & $\sqrt{ }$ & $\sqrt{ }$ \\
\hline 8 & Denmark & $\sqrt{ }$ & $\sqrt{ }$ & $\sqrt{ }$ & & \\
\hline 9 & Finland & $\sqrt{ }$ & $\sqrt{ }$ & $\sqrt{ }$ & $\sqrt{ }$ & \\
\hline 10 & France & & $\sqrt{ }$ & $\sqrt{ }$ & $\sqrt{ }$ & $\sqrt{ }$ \\
\hline 11 & Germany & & $\sqrt{ }$ & $\sqrt{ }$ & & \\
\hline 12 & India & $\sqrt{ }$ & $\sqrt{ }$ & $\sqrt{ }$ & $\sqrt{ }$ & $\sqrt{ }$ \\
\hline 13 & Indonesia & & $\sqrt{ }$ & $\sqrt{ }$ & $\sqrt{ }$ & \\
\hline 14 & Ireland & $\sqrt{ }$ & $\sqrt{ }$ & $\sqrt{ }$ & & $\sqrt{ }$ \\
\hline 15 & Italy & & $\sqrt{ }$ & $\sqrt{ }$ & $\sqrt{ }$ & $\sqrt{ }$ \\
\hline 16 & Japan & $\sqrt{ }$ & $\sqrt{ }$ & $\sqrt{ }$ & & $\sqrt{ }$ \\
\hline 17 & Malaysia & & $\sqrt{ }$ & $\sqrt{ }$ & $\sqrt{ }$ & \\
\hline 18 & Mexico & & $\sqrt{ }$ & & & \\
\hline 19 & Netherlands & & $\sqrt{ }$ & $\sqrt{ }$ & $\sqrt{ }$ & $\sqrt{ }$ \\
\hline 20 & New Zealand & $\sqrt{ }$ & & & $\sqrt{ }$ & \\
\hline 21 & Poland & & $\sqrt{ }$ & $\sqrt{ }$ & $\sqrt{ }$ & \\
\hline 22 & Portugal & $\sqrt{ }$ & $\sqrt{ }$ & & $\sqrt{ }$ & \\
\hline 23 & Romania & & $\sqrt{ }$ & $\sqrt{ }$ & $\sqrt{ }$ & \\
\hline 24 & Russia & $\sqrt{ }$ & $\sqrt{ }$ & $\sqrt{ }$ & $\sqrt{ }$ & \\
\hline 25 & Singapore & 2019 & $\sqrt{ }$ & & $\sqrt{ }$ & $\sqrt{ }$ \\
\hline 26 & South Africa & $\sqrt{ }$ & $\sqrt{ }$ & & & $\sqrt{ }$ \\
\hline 27 & South Korea & & & & & $\sqrt{ }$ \\
\hline 28 & Spain & $\sqrt{ }$ & $\sqrt{ }$ & $\sqrt{ }$ & $\sqrt{ }$ & $\sqrt{ }$ \\
\hline 29 & Sweden & $\sqrt{ }$ & $\sqrt{ }$ & $\sqrt{ }$ & $\sqrt{ }$ & $\sqrt{ }$ \\
\hline 30 & Switzerland & $\sqrt{ }$ & $\sqrt{ }$ & & $\sqrt{ }$ & $\sqrt{ }$ \\
\hline 31 & Taiwan & $\sqrt{ }$ & $\sqrt{ }$ & $\sqrt{ }$ & $\sqrt{ }$ & $\sqrt{ }$ \\
\hline 32 & Thailand & $\sqrt{ }$ & $\sqrt{ }$ & $\sqrt{ }$ & & $\sqrt{ }$ \\
\hline 33 & Ukraine & $\sqrt{ }$ & $\sqrt{ }$ & $\sqrt{ }$ & & \\
\hline 34 & United Arab Emirates & & & & & \\
\hline 35 & United Kingdom & $\sqrt{ }$ & $\sqrt{ }$ & $\sqrt{ }$ & $\sqrt{ }$ & $\sqrt{ }$ \\
\hline 36 & United States & $\sqrt{ }$ & $\sqrt{ }$ & & $\sqrt{ }$ & $\sqrt{ }$ \\
\hline 37 & Vietnam & & $\sqrt{ }$ & $\sqrt{ }$ & $\sqrt{ }$ & $\sqrt{ }$ \\
\hline
\end{tabular}

Source: TKPMGGTI (2017).

\section{Results and Discussion}

\subsection{Current Practice of Green Tax in Malaysia}

The first objective of the study is to understand the current practice of green tax in Malaysia. Based on the interview, participants generally agreed that there are two entities responsible for preserving the Malaysian environment through tax mechanism, i.e. MIDA and the IRBM. The participants also highlighted that their agencies are merely focusing on incentives. This is supported by the comments given:

"At the moment, we provide carrot, no stick, incentive-based only. The main incentives are pioneer status and investment tax allowance. Normally, the company will first apply for accelerated capital allowance. But later, when the company has improved its production, we may grant them investment tax allowance (ITA) or pioneer status. In order to approve, we have to check whether the machines used are energy-saving" (Participant 1).

"We are offering incentives and benefits to companies. For instance, for companies engaging in green project, they will come to MIDA to apply for relevant incentives. We have engagement with various stakeholders” (Participant 2$).$

The two government agencies work independently of each other. For this incentive-based mechanism, application has to be made by the company to MIDA, which chairs the committee, known as the National Committee on Investment (NCI). The NCI includes senior officials from various ministries and agencies, including the Ministry of International Trade and Industry, MOF, Economic Planning Unit, Bank Negara Malaysia, MGTC and IRBM. The Committee is tasked to consider and approve manufacturing licenses and incentives that come under its purview. In their decision-making, among others, the NCI will consider the benefit to the country, in terms of foreign exchange, the pros and cons of granting the incentives, and whether or not the benefits gained are commensurate with the costs incurred. This is important to ensure there is no manipulation or abuse of the incentive.

"We have to always look at the leakage. The MOF acts like a judge. The industry will claim that this is good. We said no, we have to do check and balance. How it benefits us (the country)? Is the benefit commensurate with the cost borne? We cannot simply grant 100\% tax exemption here and there. We are concerned with abuse, manipulation. For instance, MOF has realised that we have to save the energy as it is important to our future generation. That's why if a company has been granted with 
pioneer status for producing certain product (e.g., pen), by right, that same company can no longer be given the same exemption for the second round, if it is still producing the same product" (Participant 1).

There are a number of tax incentives available to the companies. Among them are pioneer status, ITA, accelerated capital allowance, incentive for relocating manufacturing activities, industrial building allowance, infrastructure allowance, reinvestment allowance, export incentives, group relief, etc. Of all incentives, pioneer status and ITA are the two major incentives for the manufacturing and services sectors. Pioneer status is a $70 \%-$ $100 \%$ exemption of statutory income for a period of five to 10 years. Additionally, any unabsorbed capital allowances and accumulated losses incurred during the pioneer status period can be carried forward and deducted from the post-pioneer status of the company. ITA, on the other hand, is an allowance of $60 \%-100 \%$ on qualifying capital expenditure incurred within five to 10 years from the date the first qualifying capital expenditure is incurred.

A similar trend is reported for the agriculture sector where most of the companies enjoy either pioneer status or investment incentives. Further to that, the companies in this sector may also apply for incentives for food production, which include Halal product. Companies in the services sector also enjoy the same incentives with a few more incentives, namely new investment in hotel, reinvestment in hotel and tourism projects, incentives for environmental management and research and development. As for the biotechnology industry, the companies may be eligible to apply for, among others, $100 \%$ exemption on statutory income, concessionary tax rates of $20 \%$ on statutory income, double deduction on research and development, etc. The summary of the incentives by industry is set out in Table 3 .

Table-3.Tax incentives by sector.

\begin{tabular}{|c|c|c|}
\hline Sector & Major incentives & Additional incentives \\
\hline Manufacturing & $\begin{array}{l}\text { Pioneer status and investment } \\
\text { tax allowance }\end{array}$ & $\begin{array}{l}\text { Reinvestment allowance, accelerated capital allowance, } \\
\text { industrial building system and group relief }\end{array}$ \\
\hline Agriculture & $\begin{array}{l}\text { Pioneer status, investment tax } \\
\text { allowance and incentives for } \\
\text { food production }\end{array}$ & $\begin{array}{l}\text { Reinvestment allowance, reinvestment in resource-based } \\
\text { industries, reinvestment in food processing activities, } \\
\text { accelerated capital allowance, agriculture allowance, } \\
\text { allowance on capital expenditure and incentives for } \\
\text { companies providing cold chain facilities }\end{array}$ \\
\hline Services & $\begin{array}{l}\text { Pioneer status, investment tax } \\
\text { allowance, new investment in } \\
\text { hotel, reinvestment in hotel and } \\
\text { tourism projects, incentives for } \\
\text { environmental management } \\
\text { and R\&D }\end{array}$ & $\begin{array}{l}\text { Incentives for training, incentives for approved service } \\
\text { projects and incentives for integrated logistics services }\end{array}$ \\
\hline Biotechnology & $\begin{array}{l}100 \% \text { exemption on statutory } \\
\text { income, double deduction on } \\
\text { R\&D }\end{array}$ & Concessionary tax rates of $20 \%$ \\
\hline
\end{tabular}

The above-mentioned incentives do not directly promote green initiatives. Hence, green tax incentives, which are categorised into GITA and GITE have been designed to help drive the growth of Malaysia's green economy. The purpose of the green tax incentives are: (i) to encourage investments in green technology industries and the adoption of green technology by the private sector; (ii) to encourage companies to purchase assets that have been verified as green technology assets; (iii) to facilitate the transition of expiring existing tax incentives relating to $\mathrm{RE}, \mathrm{EE}$ and green building projects; (iv) to widen the coverage across various priority green technology industries and supporting services activities; and (v) to facilitate the nation's journey to reducing $45 \%$ carbon emission by 2030. GITA is given to either assets or projects while GITE is meant for green technology services. Qualifying activities for GITA assets and GITA projects are highlighted in Table 4 and 5, respectively.

Table-4. Qualifying activities for GITA assets

\begin{tabular}{|c|c|c|}
\hline Sector/Area & Technology & Product categories \\
\hline Energy efficiency & Transformer & Energy efficient transformer (up to $33 \mathrm{kV}$ ) \\
\hline Building & Energy efficient appliances & $\begin{array}{l}\text { - Solar air-conditioning equipment/system } \\
\text { - Thermal energy storage equipment/system } \\
\text { - Variable air volume (VAV) equipment system } \\
\text { - Variable-refrigerant-volume (VRV) } \\
\text { equipment/system }\end{array}$ \\
\hline \multirow[t]{2}{*}{ Transport } & Electric vehicle & $\begin{array}{ll}\text { - } & \text { Electric motorcycle/scooter } \\
\text { - } & \text { Electric bus } \\
\text { - } & \text { Electric MPV/truck }\end{array}$ \\
\hline & Infrastructure & Electric vehicle (EV) charging equipment/system \\
\hline
\end{tabular}

Table-5. Qualifying activities for GITA projects.

\begin{tabular}{l|l}
\hline Table-5. Qualifying activities for GITA projects. \\
\hline Rector/Area & Activities \\
\hline Energy efficiency & $\begin{array}{l}\text { Commercial and industrial business entities which undertake generation of } \\
\text { energy using renewable energy resources, such as biomass, biogas, mini- } \\
\text { hydro, geothermal and solar power. }\end{array}$ \\
\hline Green building & $\begin{array}{l}\text { Companies investing in energy efficiency equipment or technologies and } \\
\text { invest in energy saving equipment. }\end{array}$ \\
\hline $\begin{array}{l}\text { Building owners of the commercial/industrial building that have been } \\
\text { awarded green. }\end{array}$ \\
\hline
\end{tabular}


While statistics on the number of companies enjoying tax incentives (including green incentives) are not easily available, the report extracted from Investment Data (2017-2019) provided by MIDA may provide some basis on the number of companies which have enjoyed the tax incentives. Generally, majority of the companies enjoying the incentives are those in the services sector with over 4,000 in both 2017 and 2018. This is followed by manufacturing companies with about 700 companies in both years. The least is the primary sector with 48 and 63 companies enjoying the incentives for 2017 and 2018, respectively. The primary sector refers to agriculture, mining, plantation and commodities. The summary is demonstrated in Table 6.

Table-6. Number of approved private investments by sector for 2017-2019.

\begin{tabular}{l|c|c|c}
\hline & $\mathbf{2 0 1 7}$ & $\mathbf{2 0 1 8}$ & Jan-March 2019 \\
\hline Primary sector & 48 & 63 & 19 \\
\hline Manufacturing sector & 687 & 721 & 214 \\
\hline Services sector & 4,731 & 4,234 & 1,445 \\
\hline Total & 5,466 & 5,018 & 1,678 \\
\hline Source: Ministry of Development Authority (MIDA) (2019).
\end{tabular}

While the number of companies enjoying the incentives is promising, interviews with the industry did not reflect the same. For instance, out of eight interviews conducted with hoteliers, two hoteliers seemed to have no idea at all about green tax incentives offered by the government. Among the comments when they were asked about the incentives are:

"Not yet. No one (in the hotel) knows about it" (Participant 3).

"We have never received any incentives. We don't have the info" (Participant 4).

Another three hoteliers claimed that they are aware of the green tax incentives but were hesitant to admit whether or not they have applied for it. These could be due to their lack of information or confidentiality status. This could be traced through their comments when asked about the incentives:

"That one (incentive), I'm not in the position to discuss" (Participant 5).

"This one (incentive), I'm not so sure. All the monetary terms I don't know. Probably you can provide information how we can do that" (Participant 6).

"I think we leave it (incentive) blank...not applicable" (Participant 7).

The remaining three participants appeared to be knowledgeable about the green tax incentives available to the hotel industry. This is illustrated through their responses to the researchers. For instance:

"MIDA actually came to us and said if certain things were invested based on environmental friendly project and it is a tourism project, we can get tax incentive. Yet, we did not apply on our own, but our holding company applied for that on a larger scale. There are only three companies within the group that can apply for it" (Participant 8).

"Yes. Now we get tax incentive for the solar panel" (Participant 9).

"I understand that we had allocated a lot of money for this chiller. We did not claim capital allowance. Instead, we got rebate of RM200 per tonne, we got 300 tonnes, so RM66,000 rebate. But there is a lot of procedure. Not flexible" (Participant 10).

The Participant from the oil and gas industry appeared to have reasonable knowledge on green tax incentives available but claimed that his company did not really enjoy the incentive. This is expressed in the following comment:

"I'm not aware of any incentives available to our company. For example, like green building, we are not really involved in that kind of business. Hence, we don't enjoy that incentive. Other things, like incentive for renewable energy, we don't do that, so again, no incentive to enjoy. Currently, we are very focused on our core business which is manufacturing chemicals, like renewable energy" (Participant 11).

Further, he commented that the cost of the project involved sometimes is not commensurate with the returns, and hence, would appreciate if there is an incentive to enjoy:

"We have come across some projects where we can see few opportunities to reduce energy consumption. But the cost of implementing the product is too high, so the return on investment is not attractive. So if we can have some kind of incentive, we can reduce excess amount of green gas emission...eventually, that would help us to implement more of those kinds of projects" (Participant 11).

In short, results from the interviews indicate that industry representatives do enjoy the tax incentives offered by the government. However, there are a few who are not aware of the availability of the incentives.

\subsection{Effectiveness of the Existing Green Tax Framework}

The second objective of the study is to examine the effectiveness of the existing green tax framework on environmental protection. One way to examine effectiveness is by observing the performance report of MIDA. It appears that tax incentives offered to companies, have to a certain extent, attracted foreign direct investment into the country. This can be evidenced with the number of approved projects throughout the years as highlighted in Table 6. This is consistent with a participant's views as highlighted below:

"The incentives offered are really effective. The number of projects that we approve is increasing every year. People are increasingly aware of various incentives offered by the government. Therefore, they are motivated to apply. For instance, those days, companies contemplated whether or not to use the solar panel, but now with the knowledge that there is tax incentive related to solar panel, without hesitation, they install the solar panel"

Further, she added:

"Generally, our aim is to encourage investment in various sectors, and to bring the technology and capital investment into Malaysia. However, in respect of green preservation, we go beyond that. We offer green tax incentives in order to support National Green agenda, i.e., to reduce gas emission by $40 \%$ by 2020 and $25 \%$ by 2030. That is our ultimate objective. In other words, green incentives act as pushing factor" (Participant 2).

The effectiveness of the existing green tax framework could be due to the efforts undertaken by the agencies involved in disseminating relevant information. 
"We organize seminars, provide briefings and collaborate with Federation of Malaysian Manufacturers and other service providers. We have B2B meetings, one-on-one meeting with companies, facilitation, etc. We assist companies who want to invest in green until they obtain the approval...incentives offered in Malaysia are very pragmatic. It is performance-based. Companies can only enjoy incentives if they have invested in particular expenditure. For instance, if companies want to enjoy green incentives, they have to use solar panel, reduce carbon emission and save energy. These incentives will expire in 2020 . But of course, we will review whether or not to continue the green incentives after that. This decision depends on target set, achievement and National Green agenda" (Participant 2).

In addition to knowledge sharing, stringent evaluation and enforcement activities are conducted to ensure the effectiveness of the implementation of the existing green tax as noted in the following comments:

"In our effort to increase foreign investment, we do carefully evaluate the applications to invest in Malaysia. Various aspects are looked into, and one of them is latest technology that promotes green environment with high productivity. I had an experience where we came across one foreign application to invest in Malaysia. We decided firmly to reject the application as the technology used is outdated that will be damaging to the environment. We did not compromise with our green environment even though the investment may be worth few hundred million. We are very clear on this matter. That's why we invite various parties for the meeting" (Participant 2).

Hoteliers do share similar views where they perceive that the existence of green tax incentives is beneficial to hoteliers in order to nurture the green practices.

\section{Conclusion}

This study explores the current practice of green tax in Malaysia and its effectiveness in achieving the intended goal of green environment. For that purpose, a qualitative approach with document reviews was conducted to answer the objectives of the study. Specifically, 11 participants representing government agencies (2) and industry players (9) were interviewed. Based on the reports and interviews, the findings indicate that Malaysia provides tax incentives, which are under the jurisdiction of IRBM and MIDA. Further, the reports also reveal that pioneer status and ITA are among the major incentives enjoyed by industries. Additionally, the reports indicate that Malaysia approved investments of over 4,000 companies in the services sector every year from 2017 to 2019. While the report may indicate that many companies are enjoying tax incentives in Malaysia, no information is available on the number of companies enjoying the green tax incentives. Interviews with industry representatives also indicate that they are not really aware of the tax green incentives available. Only a few were found to be knowledgeable about such incentives. With regard to effectiveness of the existing green tax framework on environmental protection, participants are of the opinion that the tax incentives offered are effective, considering the number of successful applications. Also, they claimed that their effort to disseminate the information at various levels and enforcement activities have helped the country to preserve the environment. Participants from the industry also concurred with the views despite their lack of knowledge on the incentives available.

The findings would definitely provide empirical evidence to the agencies involved as well as industry players. With this information, it provides a good basis for the relevant agencies to strategise on mechanisms to preserve the environment. For instance, the information on limited knowledge among industry representatives regarding tax green incentives may warrant a roundtable discussion between MIDA and companies. Theoretically, this study would add to the limited literature available and extend the knowledge boundary on the green tax setting.

This study is not without its limitations. First, is the use of interviews, which may create bias and possibility of researchers' influence on the participants. However, measures were taken to reduce such issues. For instance, participants were reminded that their responses will be reported collectively rather than on an individual basis. The interview session also allowed the participants to express their views openly with minimal intervention from interviewers. Second, the findings of the study may be limited as it focuses on the perception of government agencies and industry representatives only.

The findings and observed limitations provide insights into the potential for future studies. First, researchers may consider a survey involving a larger group of stakeholders. Second, the scope of respondents can be extended to include representatives from the community and non-governmental organisations (NGOs) in order to obtain richer data and meaningful information.

\section{References}

Bluffstone, R.A., 2003. Environmental taxes in developing and transition economies. Public Finance and Management, 1: 1-33.

Braun, V. and V. Clarke, 2006. Using thematic analysis in psychology. Qualitative Research in Psychology, 3(2): 77-101.Available at: https://doi.org/10.1191/1478088706qp063oa.

Fullerton, D., A. Leicester and S. Smith, 2008. Environmental taxes. NBER Working Paper No.14197.

Hong, L.C., 2010. A comparative study on the environmental taxation policy in Malaysia as compared to British and Australian models. Unpublished Paper. Universiti Tun Abdul Razak.

Ministry of Development Authority (MIDA), 2019. Available from http://www.mida.gov.my/home/ [Accessed 20 June 2019].

PwC, 2010. Green tax incentives for Malaysia. Kuala Lumpur: PricewaterhouseHouse Coopers.

The KPMG Green Tax Index, 2013. An exploration of green tax incentives and penalties. Available from https://assets.kpmg/content/dam/kpmg/pdf/2013/o8/kpmg-green-tax-index-2013.pdf [Accessed 10 March 2017].

TKPMGGTI, 2017. An exploration of green tax incentives and penalties. Available from https://assets.kpmg/content/dam/kpmg/ae/pdf/green-tax-index.pdf [Accessed 19 January 2018]. 